\title{
ANALISIS RISK MANAGEMENT DISCLOSURE PADA PERUSAHAAN MANUFAKTUR DI BEI TAHUN 2016-2018
}

\author{
BASUKI NUGROHO, HERNAWATI PRAMESTI
}

\author{
Fakultas Ekonomi Universitas kristen Surakarta \\ Hernawati73@yahoo.co.id
}

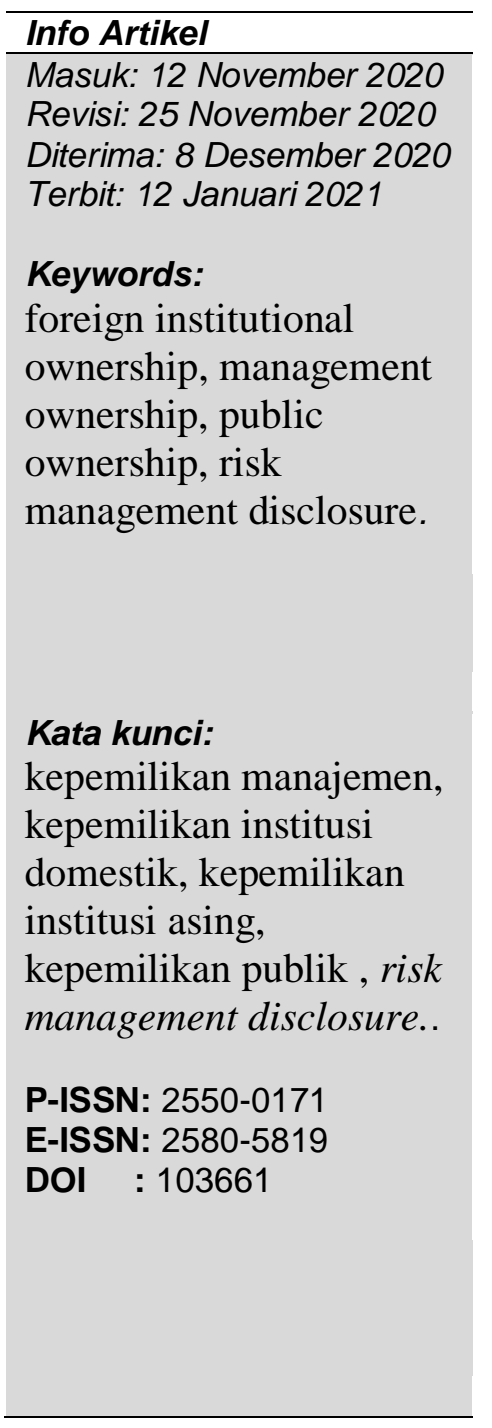

\begin{abstract}
The purpose of this study is to obtain empirical evidence of the effect of management ownership, domestic institutional ownership, foreign institutional ownership, and public ownership on risk management disclosure. The population of this research is companies listed on the Indonesia Stock Exchange and the sample used is 150 manufacturing companies. This study uses multiple regression analysis.
\end{abstract}

The results of the analysis show that there is no effect of ownership structure on risk management disclosure. From these results, it can be concluded that all of these variables have no effect on risk management disclosure.

Abstrak
Tujuan penelitian ini untuk memperoleh bukti
empiris pengaruh kepemilikan manajemen, kepemilikan
institusi domestik, kepemilikan institusi asing, dan
kepemilikan publik terhadap risk management disclosure.
Populasi penelitian ini adalah perusahaan yang terdaftar
pada Bursa Efek Indonesia dengan sampel yang digunakan
adalah 150 perusahaan manufaktur. Penelitian ini
menggunakan analisis regresi berganda.
Hasil analisis menunjukkan bahwa tidak terdapat
pengaruh struktur kepemilikan terhadap risk management
disclosure. Dari hasil tersebut maka dapat disimpulkan
bahwa keseluruhan variabel tersebut tidak memberikan
pengaruh terhadap risk management disclosure.

\section{PENDAHULUAN}

Suatu investasi yang dilakukan para investor selalu berhadapan dengan kenyataan yaitu "high risk bring about high return", yaitu apabila berkeinginan mendapatkan hasil yang banyak pasti mempunyai resiko yang besar pula. Pada setiap resiko kegiatan, perusahaan diharapkan dapat mengendalikan dan memberikan solusi sehingga tidak mengalami kerugian baik bagi perusahaan maupun bagi investor. Salah satu aspek penting dalam mengatasi risiko ini adalah mengungk risiko (Anisa, 2012). Pengungkapan informasi yang disajikan harus 
dapat dipahami, dipercaya, relevan, dan transparan, hal tersebut sangat penting dikarenakan dasar pengambilan keputusan investor, kreditor dan pengguna informasi lainnya adalah pengunkapan informasi tersebut. Selain itu penanaman modal atau investasi adalah aktivitas yang mempunyai risiko dan ketidakpastian tinggi. Karena risiko yang tinggi ini, maka pengungkapan informasi informasi yang dibagikan oleh perusahaan terhadap pihak ketiga diharapkan dapat mengurangi tingkat risiko dan ketidakpastian yang dirasakan oleh investor. Oleh sebab itu diperlukan pengungkapan (disclosure) yang memadai

Penelitian terkait pengungkapan manajemen risiko di Indonesia terbilang masih terbatas pada karakteristik pengungkapan risiko secara umum saja. Karena beberapa penelitian mengenai pengungkapan risiko di Indonesia sebatas membahas praktik pengungkapan secara umum seperti penelitian yang dilakukan oleh Dody Hapsoro (2007) meneliti tentang pengaruh struktur kepemilikan terhadap transparansi: studi empiris di pasar modal Indonesia menemukan bahwa penelitiaannya gagal mendukung hipotesis yang menyatakan bahwa proporsi kepemilikan managemen, proporsi kepemilikan institusi domestik, dan proporsi kepemilikan institusi asing berpengaruh terhadap tingkat transparansi hanya proporsi kepemilikan publik yang secara statistik signifikan berpengaruh terhadap tingkat transparansi. Sudarmadji dan Sularto (2007) melakukan penelitian mengenai pengaruh ukuran perusahaan, profitabilitas, leverage dan tipe kepemilikkan perusahaan terhadap luas voluntary disclosure laporan tahunan perusahaan dan menunjukkan hasil bahwa ukuran perusahaan, profitabilitas, leverage dan tipe kepemilikan perusahaan tidak berpengaruh secara signifikan dengan luas voluntary disclosure. Terbatasnya jumlah penelitian tentang pengungkapan manajemen risiko dan tingginya permintaan mengenai pengungkapan manajemen risiko yang dilakukan oleh investor dan pemegang saham membuat penelitian perihal manajemen risiko menjadi menarik untuk diteliti

Berdasarkan paparan di atas, maka masalah dalam penelitian dirumuskan yaitu,: Bagaimanakah Analisis Struktur Kepemilikan Terhadap Risk Management Disclosure Pada Perusahaan Manufaktur Di BEI Tahun 2016-2018

\section{TINJAUAN PUSTAKA}

\section{Definisi Risk Management Disclosure}

Pengungkapan manajemen risiko (risk management disclosure) adalah pengungkapan terhadap risiko-risiko yang telah terjadi dan dapat diselesaikan oleh perusahaan atau pengungkapan tenyang cara-cara perusahaan mengelola risiko guna menghadapi risiko-risiko 
di masa mendatang. Risk management disclosure mmepunyai kontribusi bagi para analis, investor, dan stakeholders (Fathimiya, dkk., 2012). Menurut Kristiono, dkk. (2014) pengungkapan risiko meripakan usaha dari perusahaan untuk memberikan informasi pada pengguna laporan tahunan mengenai hal-hal yang dapat menjadi ancaman perusahaan, sehingga hal-hal tersebut dapat dijadikan sebagai bahan pertimbangan untuk mengambil keputusan berivestasi. Manajemen harus bertanggung jawab atas segala aktivitas yang berada dalam perusahaannya melalui pengungkapan informasi yang tertuang dalam laporan keuangan perusahaan (Fathimiyah, dkk., 2012).

Berdasarkan Peraturan Bank Indonesia (PBI) Nomor: 11/25/PBI/2009 perubahan atas nomor: 5/8/PBI/2003. "Manajemen risiko adalah serangkaian metodologi dan prosedur yang digunakan untuk mengidentifikasi, mengukur, memantau dan mengendalikan risiko yang timbul dari seluruh kegiatan usaha bank". Berdasarkan pengertian tersebut, risk management disclosure juga bisa sebut sebagai pengungkapan atas risiko-risiko yang sudah diolah perusahaan atau dapat dikatakan sebagai pengungkapan atas usaha dan cara yang dilakukan perusahaan untuk mengontrol, meminimalisisr dan menangani risiko di masa selanjutnya. Risk management disclosure mempunyai potensi dan manfaat yang amat besar bagi para analisator, investor, dan stakeholders (Amran, et al., 2009).

\section{Definisi Kepemilikan Manajemen}

Menurut Fathimiyah, dkk. (2012) Kepemilikan Manajemen merupakan kepemilikan saham oleh pihak manajemen perusahaan. Manajemen perusahaan untuk ini berperan sebagai pengelola keberlangsungan bisnis perusahaan sekaligus sebagai pemegang saham. Pihak manajemen perusahaan bertanggung jawab terhadap seluruh kegiatan usahanya dengan cara melakukan pengungkapan informasi keuangan di dalam laporan keuangan. Semakin tinggi kepemilikan manajerial di perusahaan maka akan semakin tinggi pula tanggung jawab manajemen terkait dengan pengambilan keputusan yang berakibat tingkat risk management disclosure juga semakin tinggi.

Kepemilikan manajemen adalah besarnya proporsi saham atau tingkat kepemilikan saham oleh manajemen (Permanasari, 2010). Berdasarkan teori keagenan, perbedaan kepentingan antara manajer dan pemegang saham ini mengakibatkan timbulnya konflik yang biasa disebut agency conflict. Konfik kepentingan yang sangat potensial ini menyebabkan pentingnya suatu mekanisme yang diterapkan guna melindungi kepentingan pemegang saham. 


\section{Definisi Kepemilikan Institusi Domestik.}

Kepemilikan institusi domestik adalah kepemilikan saham oleh pihak-pihak yang berbentuk institusi, seperti bank, perusahaan asuransi, perusahaan investasi, dana pensiun dan intitusi lainnya (Fathimiyah, 2011). Peningkatan kepemilikan institusi domestik meyebabkan kinerja manjemen diawasi secara optimal sehingga manajemen menghindari perilaku yang merugikan principal. Semakin besar kepemilikan saham yang dimiliki oleh institusi akan menyebabkan usaha monitoring semakin efektif, karena dapat mengendalikan perilaku oportunistik yang dilakukan manajemen.

\section{Definisi Kepemilikan Institusi Asing}

Kepemilikan institusi asing adalah perseorangan warga negara asing, badan usaha asing, dan pemerintah asing yang melakukan penanaman modal di wilayah Republik Indonesia. Pertumbuhan yang cepat dari kepemilikan asing akan membuat perusahaan asing mengalami tekanan dari masyarakat sekitar (Rakhmawati, 2011). Sehingga, apabila semakin tinggi kepemilikan asing maka tingkat risiko investasipun semakin besar.

\section{Definisi Kepemilikan Publik.}

Kepemilikan publik akan menimbulkan atau menumbuhkan perlunya pengelolaan terhadap risiko yang lebih luas. Hal tersebut dikarenakan semakin banyak saham yang dimiliki oleh publik maka akan semakin banyak pengungkapan informasi yang harus diungkap oleh perusahaan guna memenuhi kebutuhan informasi para pemilik saham (Marisa, 2014).

Kepemilikan publik adalah kepemilikaan saham perusahaan oleh masyarakat umum atau oleh pihak luar (Fathimiyah, 2010). Adanya perbedaan dalam proporsi saham yang dimiliki oleh investor luar dapat mempengaruhi kelengkapan pengungkapan (disclosure) oleh perusahaan. Hal ini karena, semakin banyak pihak yang membutuhkan informasi tentang perusahaan, semakin banyak pula detail-detail butir yang dituntut untuk dibuka dengan demikian pengngkapan perusahaan semakin luas. Dipihak lain, ada dorongan bagi manajemen untuk selektif dalam melakukan pengungkapan informasi karena pengungkapan informasi mengandung biaya. Manajemen hanya akan mengungkapan informasi jika manfaat yang diperoleh dari pengungkapan melebihi biaya pengungkapan informasi tersebut (Marwata 2001 dalam Fathimiyah 2012). Semakin besar saham yang dimiliki oleh publik, maka semakin besar tekanan yang dihadapi perusahaan untuk mengungkapkan informasi lebih banyak dalam laporan tahunanya. 


\section{Pengembangan Hipotesis}

a. Hubungan kepemilikan manajemen terhadap risk management disclosure.

Hasil penelitian Fathimiyah, dkk. (2012) menyatakan bahwa kepemilikan manajerial tidak berpengaruh terhadap risk management disclosure. Hasil tersebut bertolak belakang dengan hasil penelitian yang dilakukan oleh Siswanto (2013) yang menunjukkan bahwa kepemilikan manajerial berpengaruh positif terhadap risk management disclosure. Oleh sebab itu, maka dirumuskan hipotesis sebagai berikut: $\mathrm{H} 1$ : Kepemilikan manajerial berpengaruh positif terhadap risk management disclosure

a. Hubungan kepemilikan institusi domestik terhadap risk management disclosure

Fathimiyah (2018) menyatakan bahwa peningkatan kepemilikan institusi domestik menyebabkan kinerja manajemen diawasi secara optimal sehingga manajemen menghindari perilaku yang merugikan principal. Semakin besar prosentase kepemilikan saham yang dimiliki oleh institusi akan menyebabkan usaha monitoring semakin efektif, karena dapat mengendalikan perilaku oprtunistik yang dilakukan manajemen. Dengan tingkat kepemillikan yang tinggi akan mengurangi agency cost pada perusahaan serta penggunaan hutang oleh manajemen. Berdasarkan uraian di atas, maka dapat dirumuskan hipotesis sebagai berikut :

$\mathrm{H} 2$ : Kepemilikan institusi domestik berpengaruh positif terhadap risk management disclosure

b. Hubungan kepemilikan institusi asing terhadap risk management disclosure

Rakhmawati (2011) menyatakan bahwa kepemilikan asing adalah perseorangan warga negara asing, badan usaha asing, dan pemerintah asing yang melakukan penanaman modal di wilayah Republik Indonesia. Pertumbuhan yang pesat dari kepemilikan asing akan membuat perusahaan asing mengalami tekanan dari masyarakat sekitar. Fathimiyah (2011) menyatakan bahwa semakin tingginya kepemilikan asing, maka semakin tinggi pula risk management disclosure.

H3: Kepemilikan Institusi Asing berpengaruh terhadap Risk Management Disclosure.

c. Hubungan kepemilikan publik terhadap risk management disclosure

Febriantina (2010) menyatakan bahwa kepemilikan publik adalah kepemilikan saham perusahaan oleh masyarakat umum atau oleh pihak luar. Fathimiyah (2011) menyatakan bahwa adanya perbedaan dalam proporsi saham yang dimiliki oleh investor luar dapat mempengaruhi kelengkapan pengungkapan oleh perusahaan. Hal ini karena, 
semakin banyak pihak yang membutuhkan informasi tentang perusahaan, semakin banyak pula detail-detail butir yang dituntut untuk dibuka dan dengan demikian pengungkapan perusahaan akan semakin luas. Di lain pihak, ada dorongan bagi manajemen untuk selektif dalam melakukan pengungkapan informasi karena pengungkapan informasi mengandung biaya. Manajemen hanya akan mengungkapan informasi jika manfaat yang diperoleh dari pengungkapan melebihi biaya pengungkapan informasi tersebut.

H4 : Kepemilikan Publik berpengaruh terhadap Risk Management Disclosure.

d. Hubungan kepemilikan manajemen, kepemilikan institusi domestik, kepemilikan institusi asing,dan kepemilikan publik terhadap Risk Management Disclosure

H5: kepemilikan manajemen, kepemilikan institusi domestik, kepemilikan institusi asing,dan kepemilikan publik berpengaruh positif signifikan terhadap Risk Management Disclosure

\section{METODE PENELITIAN}

\section{Populasi dan Sampel Penelitian}

Penelitian ini menggunakan populasi yang diperoleh sebanyak 153 perusahaan manufaktur. Setelah itu sampel diambil secara purposive

\section{Pengukuran Variabel}

a. Kepemilikan Manajemen

Kepemilikan manajemen dalam penelitian ini diukur dengan prosentase saham yang dimiliki manajemen. Semakin besar saham yang dimiliki oleh manajemen / institusi, maka semakin besar informasi yang akan diungkapkan oleh perusahaan dalam laporan tahunanya.

b. Kepemilikan Institusi Domestik

Variabel ini diukur dari jumlah prosentase saham yang dimiliki oleh institusi. Apabila suatu perusahaan terdapat lebih dari satu pemilikan institusi yang memiliki saham perusahaan, maka kepemilikan saham diukur dengan menghitung total seluruh saham yang dimiliki oleh seluruh pemilikan institusi domestik.

c. Kepemilikan Institusi Asing

Variabel ini diukur dari jumlah prosentase saham yang dimiliki oleh pihak asing dengan jumlah saham yag diterbitkan. Apabila suatu perusahaan terdapat lebih dari satu 
pemilikan asing yang memiliki saham perusahaan, maka kepemilikan saham diukur dengan menghitung total seluruh saham yang dimiliki oleh seluruh pemilikan institusi asing (Tamba, 2011)

\section{d. Kepemilikan Publik}

Variabel ini diukur dari jumlah prosentase saham yang dimiliki oleh publik. Semakin besar saham yang dimiliki oleh publik, maka semakin besar tekanan yang dihadapi perusahaan untuk mengungkapkan informasi lebih banyak dalam laporan tahunanya (Fathimiyah, 2010).

\section{Analisis Data}

a. Uji Regresi Berganda

Model regresi berganda dapat dirumuskan sebagai berikut :

$$
\mathrm{Y}=\beta 0+\beta 1 \mathrm{X} 1+\beta 2 \mathrm{X} 2+\beta 3 \mathrm{X} 3+\beta 4 \mathrm{X} 4+\varepsilon
$$

\section{PEMBAHASAN}

\section{Analisis Regresi Berganda}

Hasil dari uji regresi berganda yang dilakukan dalam penelitian ini diperoleh nilai yang tampak seperti pada tabel itu berarti :

$$
\mathrm{Y}=81.287-0.156 \mathrm{X} 1-0.161 \mathrm{X} 2-0.366 \mathrm{X} 3-0.487 \mathrm{X} 4
$$

\section{Pengujian Hipotesis}

a. Uji t (Parsial)

Hasil uji t

\begin{tabular}{|c|c|c|c|c|c|}
\hline Variabel & thitung & ttabel & Sig & $\boldsymbol{\alpha}$ & Kesimpulan \\
\hline X1 & -0.393 & 2.000 & 0.696 & 0.05 & H1 Ditolak \\
X2 & -0.717 & 2.000 & 0.477 & 0.05 & H2 Ditolak \\
X3 & -1.743 & 2.000 & 0.088 & 0.05 & H3 Ditolak \\
X4 & -1.783 & 2.000 & 0.081 & 0.05 & H4 Ditolak \\
\hline
\end{tabular}

Sumber : Data Sekunder Yang Diolah

Dari tabel terlihat nilai $t_{\text {hitung }}<t_{\text {tabel }}$. Hal ini berarti variabel-variabel bebas yang diteliti tidak berpengaruh terhadap risk management disclosure. 
b. Uji F (Simultan)

Hasil uji $\mathrm{F}$

\begin{tabular}{|l|c|l|l|}
\hline Variabel & Fhitung & Ftabel & Kesimpulan \\
\hline Risk Managemen Disclosure & 1.394 & 2.560 & H0 diterima \\
\hline
\end{tabular}

Sumber : Data Sekunder Yang Diolah

c. Uji Koefisien Determinasi $\left(\mathrm{R}^{2}\right)$

Hasil perhitungan untuk nilai $\mathrm{R}^{2}$ diperoleh angka koefisien determinasi sebesar 0.031 . Hal ini berarti 3\% variasi perubahan risk management disclosure dijelaskan oleh variasi kepemilikan managemen, kepemilikan institusi domestik, kepemilikan institusi asing dan kepemilikan publik. Sementara sisanya sebesar 97\% diterangkan oleh faktor lain yang tidak ikut terobsevasi.

\section{Pembahasan}

Dari hasil analisis diketahui bahwa: Hasil pengujian asumsi klasik menunjukkan bahwa data semua variabel berdistribusi normal dan terbebas dari normalitas, heterskedastisitas, autokorelasi, dan multikolinieritas. Pada Hasil analisis uji $t$ menunjukkan bahwa dalam kepemilikan manajemen ( $t_{\text {hitung }}-0.393$ ), kepemilikan institusi domestik ( $\left.t_{\text {hitung }}-0.717\right)$, kepemilikan institusi asing ( $\left.t_{\text {hitung }}-1.743\right)$ dan kepemilikan publik ( $\left.t_{\text {hitung }}-1.783\right)$ ternyata memiliki nilai yang lebih kecil dari $t_{\text {tabel }}(2.000)$. Dari hasil analisis uji F diketahui pengaruh secara bersama-sama dari variabel kepemilikan manajemen, kepemilikan institusi domestik, kepemilikan institusi asing, dan kepemilikan publik diketahui nilai $F_{\text {hitung }}$ (1.394) yang juga lebih kecil dari nilai $F_{\text {tabel }}$ (2.560). Dari analisis dengan menggunakan uji tersebut diketahui bahwa seluruh variabel dalam penelitian tidak berpengaruh secara parsial maupun secara bersama-sama. Sedangkan hasil uji determinasi $\left(\mathrm{R}^{2}\right)$ menunjukan bahwa variabel bebas memberikan kontribusi pengaruh terhadap variabel dependen / terikat sebesar 3\% dan sisanya sebesar 97\% dipengaruhi oleh variabel lain yang tidak masuk dalam penelitian.

\section{KESIMPULAN}

Hipotesis pertama yang menyatakan kepemilikan manajemen berpengaruh terhadap Risk Management Disclosure ditolak. Hipotesis kedua yang menyatakan kepemilikan institusi domestik berpengaruh terhadap Risk Management Disclosure ditolak. Hipotesis ketiga yang menyatakan kepemilikan institusi asing berpengaruh terhadap Risk Management 
Disclosure ditolak, demikian juga dengan hipotesis keempat yang menyatakan kepemilikan publik berpengaruh terhadap Risk Management Disclosure ditolak. Dan hipotesis kelima yang menyatakan kepemilikan institusi domestik berpengaruh terhadap Risk Management Disclosure ditolak. Hal ini diduga disebabkan tidak semua risiko yang dialami perusahaan dilaporkan secara terang-terangan karena pelaporan risiko ini akan menimbulkan kekhawatiran bagi pihak perusahaan tersebut, jadi pengungkapan secara menyeluruh cenderung dihindarkan oleh perusahaan. 


\section{DAFTAR PUSTAKA}

Anggraini, Dwi Ririn. 2011. Pengaruh Kepemilikan Institusional dan Kepemilikan Asing Terhadap Pengungkapan Pertanggungjawaban Sosial Perusahaan Dalam Annual Report (Studi Empiris Pada Perusahaan Non- Keuangan Yang Tercatat Di BEI Tahun 20082009). Skripsi S1Ekonomi. Semarang: Universitas Diponegoro.

Anisa, Windy Gessy. 2012. Analisis Faktor yang Mempenaruhi Pengungkapan Managemen Resiko (Studi Empiris Pada Laporan Tahunan Perusahaan- Perusahaan Non Keuangan yang Terdaftar di BEI Tahun 2010). Skripsi S1 Ekonomika \& Bisnis. Semarang : Universitas Diponegoro.

Fathimiyah, Venny. 2011. Pengaruh Struktur Kepemilikan Terhadap Risk Management Disclosure (Studi Survei Industri Perbankan yang Listing di Bursa Efek Indonesia Tahun 2008-2010). Skripsi S1 Ekonomi. Universitas Sultan Ageng Tirtayasa. Banten.

Fathimiyah, Venny, dkk. 2012. Pengaruh Struktur Kepemilikan Terhadap Risk Management Disclosure (Studi Survei Industri Perbankan yang Listing di Bursa Efek Indonesia Tahun 2008-2010). Kumpulan Makalah Simposium Nasional Akuntansi XV. Banjarmasin.

Ghozali, Imam. 2011. Aplikasi Analisis Multivariate Dengan Program IBM SPSS 19. Badan Penerbit Universitas Diponegoro.

Hapsoro, Dody. 2007. Pengaruh Struktur Kepemilikan Terhadap Transparansi: Studi Empiris Dipasar Modal Indonesia. Jurnal Akuntansi\&Manajemen ISSN:0853-1259.

Indriyani, Fauziah Lina. 2014. Analisis Pengaruh Struktur Kepemilikan, Komisaris Independen, dan Ukuran Perusahaan Terhadap Risk Disclosure (Studi Empiris Pada Perusahaan Manufaktur uang Terdaftar di Bursa Efek Indonesia Tahun 2013). Skripsi S1 Ekonomi Universitas Diponegoro.

Kristiono, dkk. 2014. Pengaruh Struktur Kepemilikan, Struktur Modal dan Ukuran Perusahaan Terhadap Risk Management Disclosure pada Perusahaan Perbankan yang Terdaftar di Bursa Efek Indonesia. JOM Fekon. Vol. 1 No. 2 (Oktober)

Permanasari, Wien Ika. 2010. Pengaruh Kepemilikan Manajemen, Kepemilikan Institusional dan Coporate Social Responsibility Terhadap Nilai Perusahaan. Skripi S1 Ekonomi. Universitas Diponegoro. Semarang.

Pratisto, Arif. 2009. Statistik Menjadi Mudah dengan SPSS 17. Badan Penerbit PT Elex Media Komputindo.

Rakhmawati, Desie. 2011. Pengaruh Struktur Kepemilikan, Tipe Industri, Ukuran Perusahaan, Perusahaan BUMN dan Non BUMN Terhadap Luas Pengungkapan Tanggung Jawab Sosial (CSR DISCLOSURE) pada Perusahaan di BEI Tahun 2009. Skripi. Semarang : Universitas Diponegoro. 
Sudarmadji, Ardi Murdoko dan Lana Sularto. 2007. Pengaruh Ukuran Perusahaan, Profitabilitas, Leverage,dan Tipe Kepemilikan Perusahaan Terhadap Luas Voluntary Disclosure Laporan Keuangan Tahunan. Vol 2 ISSN :1858-2559.

Tamba, Erida Gabriella Handayani. 2011. Pengaruh Struktur Kepemilikan Terhadap Pengungkapan Tanggungjawab Sosial Perusahaan (Studi Empiris Pada Perusahaan Manufacturing Secondary Sektor yang Listing di BEI tahun 2009). Skripsi S1. Semarang : Universitas Diponegoro. 